\title{
Dördüncü Sınıf Öğrencilerinin Akranlarının Problem Çözümlerini Analiz Etme Durumlarının İncelenmesi
}

\author{
Arş. Gör. Saniye Nur Ergan ${ }^{1 *}$ \\ Prof. Dr. Neșe Işık Tertemiz ${ }^{2}$
}

Gelis tarihi: 07.02 .2020

Kabul tarihi: 09.03.2020

\section{Atıf bilgisi:}

IBAD Sosyal Bilimler Dergisi

Sayı: $7 \quad$ Sayfa: 253-268

Yıl: 2020 Dönem: Yaz

This article was checked by Turnitin.

Similarity Index 10\%

Bu makalede araştırma ve yayın etiğine uyulmuştur.

\section{${ }^{1}$ Ordu Üniversitesi, Türkiye. snurergan@gmail.com \\ ORCID ID 0000-0003-4782-7710}

${ }^{2}$ Gazi Üniversitesi, Türkiye, netertemiz@gmail.com ORCID ID 0000-0003-2001-2888

* Sorumlu yazar
ÖZ

$\mathrm{Bu}$ çalışmanın amacı, ilkokul dördüncü sınıf öğrencilerinin, yaşıtları tarafindan çözülmüş problemlerle ilgili düşüncelerinin ve matematik dilini kullanma durumlarının incelenmesidir. Araştırma bir durum çalışmasıdır. Çalışma grubunu Ordu il merkezinde yer alan bir ilköğretim okulunda dördüncü sınıfa devam eden 23 öğrenci oluşturmaktadır. Araştırma verileri, çalışma grubu dışındaki dördüncü sınıf öğrencileri tarafından çözülmüş problemleri içeren çözüm kağıtları aracılığıyla toplanmıştır. Veriler örnek çözüm yollarına ilişkin öğrencilerle yapılan görüşme sonucu elde edilmiş ve veriler üzerinde içerik analizi yapılmıştır. Elde edilen bulgulara göre; ilkokul dördüncü sınıf öğrencilerinin, kendi fikirlerini matematik dilini kullanarak ifade etme durumlarına yönelik ulaşılan sonuçlarda matematiksel bir durum hakkında konuşurken problem bağlamını ve çözümü kavrayıp metin ve çözüm arasında ilişki kurabildikleri, bu ilişkiyi cümlelerinde neden-sonuç ifadelerine yer vererek açıklayabildikleri görülmektedir. Az da olsa öğrencilerin bazıları sunulan matematiksel durumu (çözümü) betimlemenin ötesine gidememişlerdir. Öğrencilerin bir başkasının çözümünü değerlendirme durumları incelendiğinde, öğrencilerin çoğunun verilen problem çözümlerine yönelik gösterim ve işlemleri doğru tespit ettikleri, hatta bazı öğrencilerin eksik gösterim ve çözüm üzerine öneri getirdikleri görülmektedir. Elde edilen sonuçlardan yola çıkarak; öğrenme ortamlarında öğrencilerin kavrama düzeylerinin ortaya çıarılmasında onlara konuşma imkânı sunmanın önemli bir öğrenme ve düzey belirlemede önemli bir aracı olduğunu söylenebilir.

Anahtar Kelimeler: Matematik dili, iletişim standardı, strateji değerlendirme, problem çözme. 


\title{
Fourth-Grade Students' Situation of Analyzing Their Peers Problem-Solving Examples
}

\author{
Res Asst. Saniye Nur Ergan ${ }^{1 *}$ \\ Prof. Dr. Neşe Işık Tertemiz ${ }^{2}$
}

First received: 07.02 .2020

Accepted: 09.03.2020

\section{Citation:}

IBAD Journal of Social Sciences

Issue: 7

Pages: 253-268

Year: 2020

Session: Summer

This article was checked by Turnitin. Similarity Index 10\%

${ }^{1}$ Ordu Universitiy, $\quad$ Turkey,
snurergan@gmail.com
ORCID ID 0000-0003-4782-7710

${ }^{2}$ Gazi Universitiy, Turkey, netertemiz@gmail.com

ORCID ID 0000-0003-2001-2888

* Corresponding Author

\begin{abstract}
In mathematics, the usage of language seen as an essential component to ensure the attendance of students, and students' need to be able to use the mathematical language efficiently. To acquire mathematical language skills, activities, which students can share their strategies and analyze them, are required. Since not all strategies are of equal value, students need to learn how to analyze others' strategies and intentions to identify their strengths and weaknesses, in other words, to criticize them. From this point, the student should not only express his / her ideas but should be able to talk about the thoughts or strategies of others. It is believed these activities can be useful for improving high-level thinking skills such as critical thinking, reasoning, and association. So it is necessary to investigate whether students are interested in others' ideas and how they express those ideas. From this point, this study aims to examine the fourth-grade students' analysis of the problem solutions of their peers' and express their ideas about these solutions by using mathematical language. This research is a case study. The study group consists of 23 students attending fourth grade in an elementary school in Ordu, Turkey. The data collected through the papers contain the solutions of fourth-grade students outside the study group. A content analysis carried on the data collected from the interviews with the students about sample solutions. According to findings; if the student understands the problem context and solution, he/she can develop a connection between the text and the solution while talking about the situation and can explain this connection by giving cause-effect statements in their talkings. Otherwise, the students could not go beyond describing the given mathematical situation. These results propose it is a critical learning and measurement tool to encourage students to share their thoughts in classrooms. According to the findings, it can be said that strong or weak language usage is also related to the level of comprehension of the problem context. It is believed that the conclusions can contribute to the understanding of the students' strategies and can enhance expressing their ideas through mathematical language. The findings of this study and some questions emerged are valuable for teachers and researchers intending to improve student achievement. As reported in the research results, some of the students described only the situation instead of evaluating the strategy. Mathematical conversations and strategy sharing exercises that teachers can make in their classrooms is an important application for eliminating this situation.
\end{abstract}

Keywords: Mathematical language, communication standard, strategy sharing, problem-solving.. 


\section{GİRIŞ}

Öğretim yaklaşımlarının değişmesiyle günümüzde öğrenciyi aktif hale getiren, öğrenci katılımını artırmayı amaçlayan bir yol izlenmektedir. Öğrencilerin öğrenme sürecinde aktif katılımcılar olarak yer alması beceri ve anlayış gelişiminde merkezi bir bileşen olarak görülmektedir (Senemoğlu, 2018). Matematik dersinde öğrencinin sürece aktif katılımında bilgiyi oluşturmak için dilin kullanılması kilit bir öge olarak görülür ve öğrencilerin, dili etkili bir şekilde kullanabilmeleri gerekir. Bu sadece yeni kelimeler öğrenme meselesi değil, aynı zamanda yeni anlam biçimleri ve tartışma biçimleridir (Halliday, 1978). Dil, bireylerin anlaşabilmek için ortaya çıkardığı, sözcük olarak ifade ettiği, anlamlar yüklediği, kurallara bağlı birimlerle anlam kazanan, canlı ve gelişim gösteren bir iletişim sistemidir. Matematik de aynı şekilde sayı, işlem, çember, alan gibi insanların geliştirdikleri kavramlarda anlam bulan, çelişmeyen aksiyomlar üzerine kurulu, canlı ve ilerleme gösteren bir iletişim sistemidir (Umay, 2002). Dil ve matematiğin birleştiği noktada karşımıza çıkan kavram ise ileri düzeyde düşünebilme becerisidir. Düşünce kişinin yaşamına anlam katarak yapıcı ilerleme göstermesine neden olduğu için değer taşımaktadır. Bu sayede kişi topluma ayak uydurabilir ve ilerlemesinde aktif görev alır (Alkan ve Güzel, 2005). Düşünme, eğitim ve iş yaşamındaki başarıda gerek duyulan becerilerin yanı sıra yaşamda ihtiyaç duyulan temel becerileri de kapsamaktadır. İnsanlığın varlığından bu yana bilimsel ve sosyal gelişimini temel alan eğitim felsefelerinin özünde de düşünmeyi geliştirme yer almaktadır. Bu eğitim felsefelerine göre matematik de bireylerin düşünme becerilerini geliştirerek, bireylere öğretilmesi gereken temel disiplinlerden biri olarak ele alınmaktadır. Matematiksel düşünmenin ne olduğu sorusuna verilecek ortak bir tanım bulunmamaktadır. Bu da araştırmacıların bu konuda farklı bakış açılarına sahip olmalarından ve farklı dil ve terminolojiyi kullanmalarından kaynaklanmaktadır. Genel olarak matematiksel düșünme iki farklı perspektiften ele alınmaktadır (Isoda ve Katagiri, 2012, Akt. Çelik, 2016). Birincisi matematiksel düşünmeyi varsayımda bulunma, genelleme ve kanıtlama gibi matematiksel süreçler bakış açısından ele alırken (Burton, 1984; Polya, 1945; Schoenfeld, 1992; Stacey, 2006, Akt. Çelik, 2016); diğeri matematiksel kavramların gelişimi bakış açısından (Dreyfus, 2002; Freudenthal, 1973; Tall, 1995, Akt. Çelik, 2016) ele almaktadır.

Matematiksel düşünmeyi süreç bakış açısından ele alan yaklaşım "Matematiksel düşünme nasıl gerçekleşir?" sorusuna odaklanır. Bir problem durumuna karşı başlatılan ve sürdürülen düşünme eylemleri matematiksel düşünme süreçleri olarak bu kategoride ele alınmaktadır. Matematiksel düşünmeyi matematiksel kavramların gelişimi bakış açısından ele alan yaklaşım ise matematiksel içeriğe odaklanır ve bireyin matematiksel kavramları nasıl yapılandırdığı, yapılandırma sürecinde hangi aşamaların bulunduğunu ele almaktadır. Harel ve Sowder' a (2005) göre öğrencilerin bir terim, ifade veya bir cümleye yükledikleri anlam, bir probleme ürettikleri çözüm, bir iddianın doğrulanabilirliği ya da yanlış olduğunu göstermek için savundukları gerekçeler birer anlama biçimi iken böylesi eylemlerin temelini oluşturan ve öğrencilerin hâlihazırda sahip olduğu genel teoriler ise düşünme biçimidir. Daha açık bir ifade ile bireyin belli bir matematiksel durumda lokal olarak yaptığı akıl yürütmeler anlama biçimini, benzer nitelikte birçok durumda kullanılan akıl yürütmeler ise düşünme biçimini ifade etmektedir. Matematiksel düşünmeye yönelik farkındalık oluşturmak ve bilgi düzeyini artırmak için kullanılan farklı yöntemlerinin bulunduğunu gösteren öğretim uygulamaları vardır. Literatürde bu uygulamalar bilişsel muhakemeye dayalı öğretim, ders araştırması, öğrencilerin matematiksel çalışmalarını inceleme, öğretmenlerin videoya kaydedilmiş derslerini incelemesi, matematik öğretimi ile ilgili örnek olayların incelenmesi ve karma uygulamalar olarak yer almaktadır (Öztürk ve Akyüz, 2013). Öğrencilerin fikirlerinin incelenmesini amaçlayan teorilerden biri olan RBC teorisi öğrenenin ön bilgilerine dayanarak nasıl yeni yapılar oluşturduğuna odaklanmıştır. Dreyfus, Hershkowitz ve Schwarz RBC (Recognizing- Building with- Constructing) olarak adlandırdıkları bir model geliştirmişlerdir. Üç bilișsel eylemin (tanıma, kullanma, olușturma) bas harfleri modele ismini vermektedir. Dreyfus (2007) tarafindan bu soyutlama sürecine pekiştirme (consolidation) bilişsel eyleminin de eklenmesiyle, $\mathrm{RBC}+\mathrm{C}$ soyutlama modeli şeklindeki son halini almıştır. $\mathrm{Bu}$ modelin esası bilginin soyutlanması ve yeni kavramlar oluşturulma sürecinin incelenmesidir. Öğrencinin bilgiyi oluşturma süreci aslında bilginin soyutlanması ile doğrudan ilgilidir. Bilginin soyutlanması özellikle de matematik eğitiminde sıklıkla karşımıza çıkmaktadır. Çünkü matematik bir soyutlama bilimidir ve matematiksel kavramlar soyutlama sonucu elde edilmektedir (Altun, 2008). Bireylerin soyutlama yapabilmesi için izlediği yollar ve bilgiyi oluşturma süreçlerinin derinlemesine incelenmesi, öğrencilerin hangi süreçte ya da eylemde 
zorlandıklarının anlaşılmasına ve zorlanılan konuya odaklanarak sorunun çözülmesine yardımcı olur. Araştırmacılara göre soyutlamanın gerçekleşmesi için yeni bir matematiksel yapıya ulaşmak için eski yapıların yeniden düzenlenmesi, bunlar arasında bağlantı ve ilişki kurulması, bunların tek bir matematiksel düşünce süreci içinde birleştirilmesi gerekmektedir (Dreyfus, 2007). Bilişsel yapılların oluşumunu gözlemlemek zordur çünkü bu yapıların oluşumu çok sıklıkla gerçekleşmemektedir ve bunların gözlemleneceği deneyleri tasarlamak da oldukça zordur. Ancak bu modelde, soyutlama sürecini öğrencilerin sözlü ifadeleri ya da fiziksel eylemleri vasıtasıyla gözlemlenebilen zihinsel eylemleri olan bilişsel eylemler üzerinden çalışılmaktadır. Bu noktada da yeniden öğrencilerin sözlü ifadelerinin onların matematiksel düşüncelerini incelemede bir temel olarak ele alınmasının anlamlı bir çıkış noktası olduğu görülmektedir. Öyle ki Amerika'da birçok eyaletin takip ettiği Ortak Eyalet Matematik Standartlar1Common Core State Standards for Mathematics (CCSSM, 2010) 'uygun argümanlar oluşturabilir ve başkalarının akıl yürütmelerini eleştirebilir' standardını tüm sınıf seviyelerinde kabul edilmiştir. Benzer şekilde öğrencilerin matematiksel düşünmelerini iletişim yoluyla organize etmeleri gerektiğini ifade eden bir kavram olan İletişim Standardına, öğretim programları aracıllı̆ıyla ulaşılması gerektiği belirtilmiştir (NCTM, 2000). İletişim standardına göre öğrencilerin başkalarının fikirlerini ve stratejilerini anlama ve bunların anlamlı olup olmadığına karar vermesi kısaca değerlendirmesi gerekir.

Verimli konuşmalar için iletişim standardının her iki boyutu da (başkalarının stratejilerini analiz etme ve matematiksel dili kullanma) gereklidir. Bu boyutlar iletişim aracılığıyla matematiksel düşünmeyi güçlendirme, bilgileri organize etme, fikirlerini paylaşırken matematiği kullanabilme, matematiksel düşüncelerini arkadaşlarına, öğretmenlerine ve başkalarına açık ve tutarlı bir şekilde aktarabilme, başkalarının matematiksel düşünme ve stratejilerini analiz etme, değerlendirme ve matematiksel fikirleri açık bir şekilde ifade etmede matematiksel dili kullanma becerilerini kapsar (NCTM, 2000). Bu becerilerin kazanılması için öğrencilerin birbirleriyle stratejilerini paylaşıp bunları analiz edebildikleri etkinlikler gerekir. Bu tür etkinlikler öğrencilerin icat ettiği stratejileri tartıştığı ve stratejileri bir eleştiri nesnesi haline getirebildiği bir zemin sağlar. Tüm stratejiler eşit değerde olmadığından, öğrencilerin güçlü ve zayıf yönlerini belirlemek, bir başka deyişle eleştirmek için başkalarının yöntem ve fikirlerini incelemeyi öğrenmeleri gerekir. Bu açıdan bakıldığında öğrenci yalnızca kendi fikirlerini açıklamakla kalmamalı başkalarının fikirleri üzerine konuşabilmeli, başkalarının eylemlerini sorgulayabilmelidir (Hintz ve Kazemi, 2014). Bu amaçlara hizmet edecek olan etkinliklerin eleştirel düşünme, akıl yürütme, ilişkilendirme gibi üst düzey düşünme becerilerinin geliştirilmesinde etkili olacağı düşünülmektedir.

Bu konuda yapılan çalışmaların problem çözme stratejilerini paylaşma seviyeleri ile problem çözme başarısı arasındaki ilişkiye (Webb, Franke, Ing, Wong, Fernandez, Shin ve Turrou, 2014), sınıf ortamındaki paylaşımların öz yeterliliğin geliştirilmesi üzerindeki etkisine (Yetkin Özdemir ve Pape, 2013), öğretmenlerin öğrencilerin sınıf içi üretici konuşmalara yönelmelerindeki rolüne (Webb, Franke, Ing, Turrou, Johnson ve Zimmerman, 2017) ve sınıf içi tartışmaların nasıl güçlendirilebileceğine (Hintz, 2014) yönelik olduğu görülmektedir. Araştırma sonuçlarında; öğrencilerin strateji paylaşımı gibi üretken matematiksel tartışmalar yürütmesi öğrencilerin matematiksel kavramlar ve işlemlerle ilgili anlayış ve etkinlik geliştirmelerine yardımcı olduğu (Chapin, O'Connor ve Anderson, 2009; akt. Hintz, 2014), başkaları tarafından yapılan iddiaları dikkatlice incelemenin öğrencilerin matematik hakkında eleştirel düşünürler olmasını sağladığı (NCTM 2000), problem çözme stratejilerini paylaşma seviyeleri ile problem çözme başarısı arasında pozitif bir ilişki olduğu (Webb ve diğerleri 2014), konuşma yoluyla öğrencilerin matematiksel hataları tartışma, kişisel stratejilerin paylaşma ve sınıf arkadaşlarının çözümlerini dinleme imkanı bulduğu (Hintz, 2014) ifade edilmiştir. Ayrıca ilgili araştırmalarda çoğunlukla sınıf içi grup tartışmaları ve bu etkinliklerin sağladıkları üzerinde durulduğu görülmüsşür ancak öğrencilerin bir başkasının stratejisini değerlendirme ve bu durum üzerinde matematik dilini kullanarak açıklamalar yaptığı bir çalışmaya rastlanmamıştır. Hâlbuki bir başkasının stratejisini değerlendirme Organisation for Economic Co-operation and Development (Ekonomik İş birliği ve Kalkınma Örgütü, OECD) tarafindan duyurulan Eğitim-2030 belgesinde 'geleceğe en iyi hazırlanan ögrenciler, başkalarının niyetlerini, eylemlerini ve duygularını anlayabilir' ifadesi ile kendine yer bulur (OECD, 2018). Bu ifade matematik disiplininde yorumlandığında başkalarının matematiksel düşünme stratejilerini analiz etme ve değerlendirme olarak karşımıza çıkar.

Başkalarının matematiksel düşünme stratejilerini analiz etme ve değerlendirme Milli Eğitim Bakanlığı (MEB) Matematik Dersi Öğretim Programlarında (MEB, 2018, s. 8) özel amaçlar içinde "problem 
çözme sürecinde kendi düsünce ve akal yürütmelerini rahatllkla ifade edebilecek, başkalarının matematiksel akl yürütmelerindeki eksiklikleri veya boşlukları görebilecektir" ifadesiyle yer almaktadır. Öyleyse öğrencilerin başkalarının fikirleriyle ilgilenip ilgilenmedikleri ve bu fikirleri nasıl ifade ettikleri ile ilgili araştırmaların yürütülmesi gereklidir. Çünkü konuşmalar matematik derslerinde öğrenmenin yaygın ve önemli bir parçasıdır ve öğrencilerin bir başkasının stratejisini değerlendirme durumlarının yanında fikirlerini matematik dilini kullanarak açıklama durumlarının incelenmesi gerekli görülmektedir. $\mathrm{Bu}$ noktadan hareketle çalışmanın amacı, ilkokul dördüncü sınıf öğrencilerinin yașıtları tarafından çözülmüş problemleri analiz etme ve bu çözümlerle ilgili fikirlerini, matematik dilini kullanarak ifade etme durumlarının incelenmesi olarak belirlenmiştir.

\section{YÖNTEM}

$\mathrm{Bu}$ araştırma, ilkokul dördüncü sınıf öğrencilerinin yaşıtları tarafından bağımsız olarak çözülmüş problemleri analiz etme ve bu çözümlerle ilgili fikirlerini, matematik dilini kullanarak ifade etme durumlarının sistematik yaklaşımla incelenmesine yer veren nitel bir çalışmadır.

\section{Araştırmanın Deseni}

Araştırma bir durum çalışması olarak tasarlanmıştır. Durum çalışması, bir ortam, tek bir konu, doküman veya belirli bir olayın ayrıntılı bir incelemesidir (Merriam, 1988, Yin, 1989; Stake, 1994 Akt. Bogdan ve Biklen, 2007, s. 59). Durum çalışmasının temel özelliği 'durum' un detaylı şekilde araştırılmasıdır. Durum çalışmaları kendisinden sonra yapılacak araştırmalar için oldukça detaylı bir bilgi sağlayacağı ve spesifik bir duruma yoğunlaştığından oldukça önemli bir desendir. Durum çalışmalarında birçok veri toplama yöntemi kullanılabilir; durumlar birbirinden farklı olduğu için genelleme söz konusu değildir (Yıldırım ve Şimşek, 2011, s. 77). Bu çalışmada “durum” ilkokul dördüncü sınıf öğrencilerinin çözülmüş problemleri analiz etmeleri ve bu çözümler üzerine konuşarak kendi matematiksel fikirlerini, matematik dilini kullanarak açıklamalarıdır. Durum çalışmasının sahip olduğu en belirgin nitelik güncel bir olgu, olay, durum, birey ve gruplar üzerine odaklaşıp, ayrıntılı bir şekilde incelemeye çalışmasıdır (Bassey, 1999; Stake, 1995; Yin, 1994; Akt. Ekiz, 2003, s. 43). Durum çalışması, çalışma yapılan konu hakkında ayrıntılı bilgilere ulaşmayı ve olayı her açıdan anlamayı amaçlayan bir araştırma şeklidir. Yin'e (2003) göre, betimleyici durum çalışmalarında bir durum hakkında yeterli bilgi olmadığında bir veya iki örnek olay kullanılarak o durum hakkında derinlemesine bilgi elde edilmesi amaçlanmaktadır. Bu çalışmada konuyla ilgili şimdiye dek ulaşılmamış olan bilgilere yönelik detaylı bilgi edinilmesi amaçlandığından araştırma, durum çalışması modellerinden betimsel durum çalışması olarak tasarlanmıştır.

\section{Çalışma Grubu}

Nitel araştırmalar küçük bir örneklemle gerçekleştirilir. Nitel araştırmalarda verilerin evrene genellenmesi amaçlanmadığından istatistiksel temsil edilebilirlik yerine, durumun derinlemesine incelemesi söz konusudur. Örneklemin araştırmanın gereksinin duyduğu bilgiyi karşılaması önemlidir (Yıldırım ve Şimşek, 2011; Karasar, 2016). Araştırmanın çalışma grubunu, Ordu İli Merkez ilçesinde yer alan bir okulda ilkokul dördüncü sınıfa devam eden 23 öğrenci oluşturmaktadır. Çalışma grubu belirlenirken kolay ulaşılabilir örnekleme yöntemi benimsenmiştir. Ayrıca çalışma grubu araştırmacının her hafta gözlemci olarak bulunduğu bir sınıftan tercih edilmiştir. Bu tercihin nedeni öğrencilerin görüşme esnasında yabancılık duymasının önüne geçmektir.

\section{Veri Toplama Aracı ve Veri Toplama Tekniği}

Nitel araştırmayı "gözlem görüşme ve doküman analizi gibi nitel veri toplama tekniklerinin kullanıldığı, algıların ve olayların doğal ortamda gerçekçi ve bütüncül bir biçimde ortaya konmasına yönelik nitel bir sürecin izlendiği araştırma" olarak tanımlamak mümkündür (Yıldırım ve Şimşek, 2011). Çalışmanın doğasına uygun olarak araştırma verilerini elde etmek için öğrencilerle birebir görüssme yapılmış ve yazılı dokümanlar olan çalışma kağıtları veri toplama aracı olarak kullanılmıştır. Dokümanlar, veri toplama aracı olarak tek başına kullanılabileceği gibi diğer alan gözlemleri ve görüşmelerden derinlemesine bilgi elde etmek amacıyla da kullanılabilir. Kişisel belgeler, günlükler, mektuplar, otobiyografiler, notlar, politik yazınlar, medyada yazılanlar, film, fotoğraf gibi veri kaynakları nitel araştırma çerçevesinde yardımcı olabilecek kaynaklardır (Maykut ve Morehouse, 1994, s. 106). Araştırma verileri, çalışma grubu dışındaki dördüncü sınıf öğrencileri tarafindan çözülmüş problemleri 
içeren çözüm kağıtları aracılığıyla toplanmıştır. Yetişkin araştırmacılar ya da öğretmenler tarafindan yapılandırılan çözüm örnekleri yerine yaşıtları tarafından bağımsız olarak çözülmüş örnekler üzerinden çalışmak kullanılan çözüm kağıtlarının öğrenci seviyesine uygunluğun sağlanması açıssndan önemli görülmektedir. Araştırmada kullanılmak üzere seçilen çözüm örnekleri belirlenirken:

- öğrencilerin üzerine konuşmasına teşvik edecek şekil- resim gibi ögeler içermesi,

- model, sonuç ve gidiş yolu bakımından birbirinden farklı olması,

-açık ve anlaşı1ır nitelikte çözülmüş olması dikkate alınmıştır. Araştırmada ele alınan problem dört işlem becerisine dayalı ve Matematik Dersi Öğretim Programının dördüncü sınıfında yer alan 'Doğal sayılarla çarpma işlemi gerektiren problemler çözer, Doğal sayılarla toplama işlemi gerektiren problemler çözer' (MEB, 2019) kazanımlarına uygun olarak seçilmiştir. Seçilen problem çözümleri alanda uzman bir profesör ve araştırma görevlisinin yukarıda belirlenen kriterlere göre fikir birliği ile seçimleri sonucunda üç farklı çözüm veri toplama aracı olarak kullanılmıştır. Ayrıca problem çözümleri seçilirken iki doğru çözüm ve bir eksik çözüm tercih edilmiştir. Seçilen doğru çözümlerin görsel temsil türü ve işlemler bakımından farklı olması ve öğrencinin bu çözümler arasındaki strateji farkını görmesi beklenirken eksik çözümün sonucunun ve çözümde kullanılan stratejinin diğer çözümlerden farklı olması tercih edilmiştir. Problem ve seçilen çözüm yolları aşağıdaki gibidir:

Problem: A model araçlar 5 kişilik, B model araçlar ise 7 kişiliktir. A model araçlardan 3 tane ve $B$ model araçlardan 4 tane yola çıklyor. Araçlar tamamen dolu olduğuna göre toplam yolcu sayısı kaçtır?
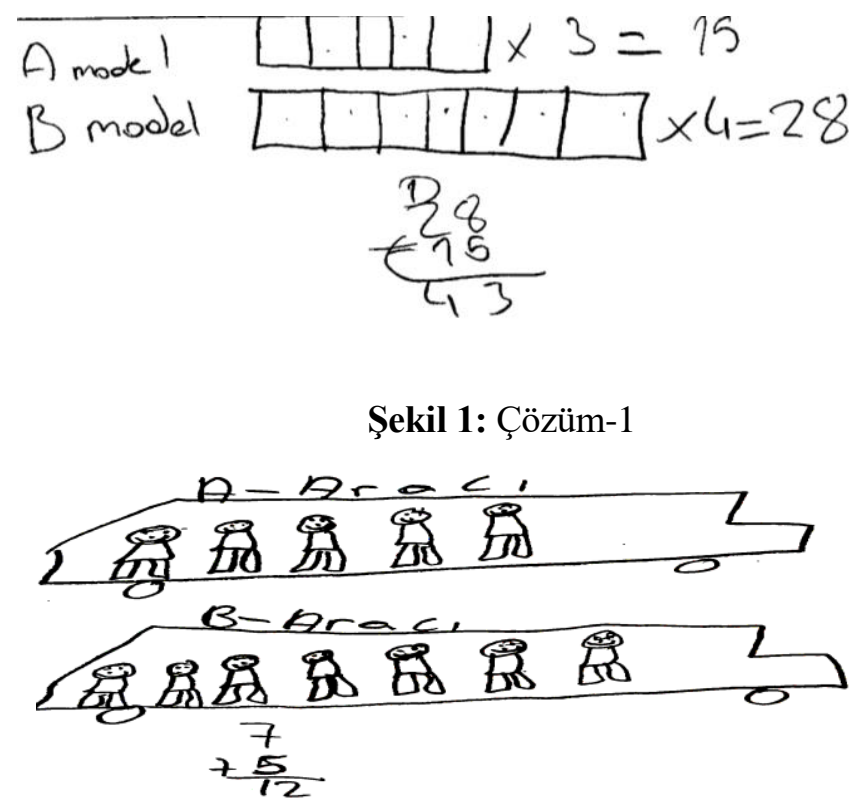

Şekil 2: Çözüm-2
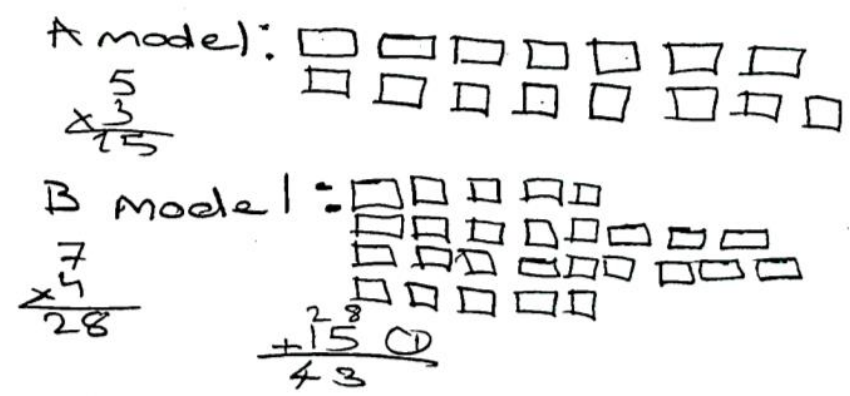

Şekil 3: Çözüm-3

Çalışmada veriler araştırmacılar tarafından Şekil 1, 2 ve 3’te sunulan problem çözümleri üzerine öğrencilerle görüşme yoluyla elde edilmiştir. 


\section{Veri Toplama Süreci}

Görüşmelerin öncesi, gerekli resmi izinlerin alınması ve okul yönetimi, ilgili öğretmen ve çalışmaya katılacak öğrencilerin velilerinden onay alınmasını takiben araştırmaya katılacak öğrencilere araştırmanın amacı ve kapsamının detaylı bir biçimde anlatılmasını içermektedir. Çalışmanın öğrenciyi başarı yönünden ya da görüşmecinin sorularının doğru ya da yanlış cevaplanmasının önemli olmadığı, yalnızca sürecin incelenmesinin amaçlandığı açıklanmıştır. Görüşme okul tarafından tahsis edilen bir odada gerçekleştirilmiş ve ses kayıt cihazı aracılığıyla kaydedilmiştir. Böylelikle görüşme ortamının kısa süre sonra unutulmasının önüne geçilmiştir. Görüşmeler sırasında, öğrencilerin düşüncelerini açığa çıkarmak için seçilen örnek çözümler öğrencilere çalışma kâğıtları ile yöneltilmiş ve araştırmacıyla olan sözlü ve sözsüz iletişimleri kaydedilmiştir.

Çözüm kağıtları önce öğrencilere tek tek gösterilmiş ardından üç çözüm birlikte gösterilerek öğrencilerden çözümleri kendi cümleleriyle anlatmaları ve kullanılan stratejileri karşılaştırarak açıklamaları istenmiştir. Araştırmada öğrencilere çözüm hakkında konuşmalarını sağlayacak olan 'bu çözümü anlatır mısın, sence bu çözümle diğeri arasındaki benzerlikler/farklar nelerdir, bu problemi çözen biri hangi aşamalardan geçer, bu problemi çözerken nerede sorun yaşanmış olabilir, farklı çözümler görmek senin için ne ifade ediyor, kullanılan yöntem etkili olmuş mudur, bu problemi çözen biri hangi bilgilerden faydalanmıştır, eksik olan işlemin nedeni nedir, sen olsan farklı nasıl çözerdin, bu problemi çözen bir kişi ne öğrenmiş olabilir' soruları yöneltilmiştir. Bireysel olarak yapılan görüşmeler her öğrenci için her bir çözüm yaklaşık 8 dakika sürmüştür.

\section{Araştırmacının Rolü}

Nitel araştırmalarda araştırmacının rolü oldukça önemlidir. Çünkü nitel araştırmalarda, araştırmacı konuyu ve katılımcıları daha iyi anlayıp analiz edebilmek için çalışmaya bizzat katılan, kavramların ortaya çıkmasını uygun ortamı soruları ile yönlendiren, katılımcılarla birebir görüşen kişi konumundadır, yani sürecin bir parçasıdır. Bu araştırmada araştırmacı öğrencilerle sohbet eden, fikirlerini ifade etmelerini sağlamak için yardımcı sorular kullanan kişidir.

\section{Verilerin Analizi}

Öğrencilerle yapılan görüşmelerin ses kaydından yazılı metinlere dönüştürülmesini takiben veri analizi süreci başlamıştır. Bu süreçte araştırma amacına uygun olarak veriler üzerinde içerik analizi yapılmıştır. İçerik analizinin uygulanması birkaç aşamada gerçekleştirilmektedir. Birinci aşama analitik betimleme ve kodlamadır. Bu kısımda verinin birtakım kategorilere bölünmesi söz konusudur. Kodlama analiz kategorilerinin saptanmasıyla başlar. Analiz kategorileri veri ile ortaya konulması istenen boyutlarla ilgilidir (Bilgin, 2014). Kategorilerin belirlenmesinde dikkat edilmesi gereken bazı noktalar vardır. Kategorilerin homojen, ayırt edici, objektif, bütünsel, amaca uygun ve anlamlı olmasına dikkat edilmelidir (Bardin, 1977 akt. Bilgin, 2014). Kategorilendirme aşamasında benimsenebilecek iki yaklaşım vardı. Birinci yaklaşımda var olan bir kategori sistemi kullanılır bu kapalı yaklaşım olarak adlandırılır. Açık yaklaşım olarak adlandırılan diğer yolda ise kategoriler önceden saptanmamıştır; veri ele alındıktan sonra bu kategoriler oluşturulur (Bilgin, 2014). Bu araştırmada benimsenen açık yaklaşım ile aşağıdaki kategoriler oluşturulmuştur:

Fikirlerin ifade edilmesinde matematiksel dilin kullanımı

Verilen çözümü probleme dayalı açıklama

Problemden bağımsız yalnızca verilen çözüme odaklanma

Problemi ve verilen çözümü anlayamama

Bir başkasının stratejisini anlama

Bir başkasının stratejisini değerlendirme

Verilen çözümü probleme dayalı değerlendirme

Verilen çözümdeki eksikleri belirleyip öneride bulunma 
Kategorilerin belirlenmesinin ardından içerik analizinin çıkarım basamağı başlamıştır. Bu basamakta veriyi kuşatan neden- sonuç ilişkileri veya veri kaynaklarının özellikleri hakkında çeşitli yordamalar yapılır. Yordamalar analizi yapılan konuya özgü nitelik taşır ve genellenemez (Bilgin, 2014). İçerik analizi yönteminin geçerlik ve güvenirliği temelde kodlayıcı güvenirliği ve kategorilerin belirli ve tutarlı olma durumuna bağlıdır. Araştırmanın geçerlik ve güvenirliği başlığında bu hususlara ayrıntılı olarak yer verilmiştir.

\section{Araștırmanın Geçerlik ve Güvenirliği}

Nitel araştırmalarda geçerlik ve güvenirliğin sağlanması için nitel araştırmanın doğasına uygun olan inandırıcılık, aktarılabilirlik, tutarlılık ve doğrulanabilirlik terimleri kullanılır (Lincoln ve Guba, 1985 akt. Creswell, 2013). Bu araştırmada inandırıcılık, derinlik odaklı veri toplama ve uzman incelemesi stratejileri ile sağlanmıştır. İnandırıcılık sağlamaya yönelik stratejiler olarak önerilen (Yıldırım ve Şimşek, 2011) bu stratejilerden derinlik odaklı veri toplamada araştırmacıların elde ettiği sonuçları birbiriyle karşılaştırarak bazı örüntülere ulaşacak şekilde incelemesi yoluyla sağlanmıştır. Araştırmanın uzman incelemesi boyutunda araştırma sürecinde uzmanlar arasında düzenli toplantılar yapılmış̧ır. Bunun amacı araştırma deseni, veri toplama ve analiz, sonuçlara ulaşma ve yorum aşamalarının geçerli ve tutarlı olmasına katkı sağlanmasıdır. Ayrıca tüm sürecin detaylı anlatımı ve ham verinin doğrudan alıntılarla sunulmasının inandırıcılık için önemli görülmektedir (Creswell ve Miller, 2000). Araştırmanın yöntem başlığı altında bu bilgiler ayrıntılı biçimde yer almaktadır. Güvenirliğin sağlanması için kodlayıcılar arası görüş birliği desteklenmektedir (Silverman, 2005). Araştırmada kodlayıcı güvenirliği kapsamında üç uzmanla (bir profesör ve iki alan uzmanı) veriler paylaşılarak kodlayıcılar arasında yapılan değerlendirmeler, araştırma verileri ve bulgular arasında uyum olduğunu göstermiştir. $\mathrm{Bu}$ adımlar araştırmanın tutarlık ve teyit edilebilirlik özelliklerinin sağlanması için yeterli görülmüştür.

\section{BULGULAR VE YORUMLAR}

$\mathrm{Bu}$ çalışmada elde edilen veriler fikirlerin ifade edilmesinde matematiksel dilin kullanımı, bir başkasının stratejisini anlama-değerlendirme ve farklı çözümler görmenin nasıl bir deneyim olduğuna yönelik öğrenci ifadeleri başlıkları altında sunulmuştur.

\section{Fikirlerin İfade Edilmesinde Matematiksel Dilin Kullanımı}

Öğrencinin matematiksel dili kullanımı yapılan açıklamanın gerekçesini içerdiğinde, sunulan duruma yönelik neden-sonuç ilişkisi içinde anlama ve açıklamaya dayalı ifadeleri verilen çözümü probleme dayalı açıklama kategorisinde, neden-sonuç ifadelerini içermeyen, bir başkasının problem çözme sürecinin değerlendirilemeyip yalnızca betimlendiği ifadeler ise problemden bağımsız yalnızca verilen çözüme odaklanma kategorisinde değerlendirilmiştir. Öğrencilerin bir başkasının çözümü hakkında konuşurken kullandığ 1 dil matematikle ilgili konuşma dilidir. Matematiksel dil genellikle öğrencilerin kavramları kullanarak durumları açıklaması temelinde değerlendirilmektedir (Çalıkoğlu-Bali, 2003). Ancak bu çalışmada matematiksel dil gerekçeleri belirterek matematiksel bir durum hakkında konuşmak olarak değerlendirilmiştir. Alanyazında matematik dili farklı ölçme araçlarıyla değerlendirilmektedir. Örneğin Çalıkoğlu (2002), matematik öğretiminde dil ölçeğini geliştirirken matematik dilinin bileşenlerini sözlü anlatım, yazılı anlatım, sembolik anlatım ve problem oluşturma olarak belirtmiştir. $\mathrm{Bu}$ araştırmada matematik dili, sözlü anlatımların incelenmesi aracılığıyla değerlendirildiğinden araştırma, dilin konuşmaya dönük boyutuyla sınırlıdır. Çalışmanın fikirlerin ifade edilmesinde matematiksel dilin kullanımının incelenmesi boyutunda öğrencilerden gördükleri çözümü kendi cümleleriyle anlatmaları istendiğinde öğrenciler çeşitli anlatımlar yapmıştır. Bu anlatımlar yapılan analizler sonucu belirlenen kategoriler etrafinda sunulmuştur.

\section{Verilen Çözümü Probleme Dayalı Açıklama}

Çalışmaya katılan 23 öğrenciden 13' ü Çözüm-1'e yönelik olarak problemi çözen öğrencinin ne düşünmüş olabileceğiyle ilgili görüşlerini verilen çözümü probleme dayalı olarak doğru bir şekilde açıklamıştır. Bu gruptaki öğrenciler önce problemi okumuşlar daha sonra da verilen çözümü değerlendirmişlerdir. Bu gruptaki öğrenciler verilen durumu daha çok neden-sonuç ilişkisi içinde ele almışlar ve akranlarının nasıl akıl yürüttüklerini problemin çözüm sırasına göre açıklamışlardır. Örneğin; 
Ö2: Her araçta kaç yolcu olduğunu önce göstermiş. A model 5 kişilikmiş A aracında 3 tane varmış. Önce A aracını göstermiş 3 kişilik olduğuna göre bunları göstermiş. A model araçlar 5 kişilik olduğundan daha kolay bulmamız için 3'le çarpmamız gerekir sonuçta 15 bulmuş. 15 A aracındaki toplam kişi sayısı. B model araçlar 7 kişilikmiş burada da 4 tane araba yola çıkmış. Aynısını yapmış 7'yle 4'ü çarpmış. 28 bulmuş. Bunlar 15 ve 28 A model ve B modelin yolcu sayısı. Bunları toplamış 43'ü bulmuş. Bu doğru yapmış.

Ö10: İlk önce A'yl göstermiş 5 kişilik sonra B'yi 7 kişilik göstermiş. A modeli 3 tane olduğu için 3'le çarpmış 15 çıkmış. B modeli 4 araç olduğu için 28 yapmış. Toplam yolcu sayısını sorunca da $28^{\prime} l e 15$ ' $i$ toplamıs.

Ö20: A model araçlar 5 kişilik olduğu için 5 tane kare yapmış. B modeller de 7 kişilik olduğu için 7 tane kare yapmış. 3 tane A aracından olduğundan 3'le çarpmış 15. 3tane A modeldeki kişilerin sayısını bulmuş. B'de de 7 kişilik 4 tane araç olduğundan 28 kişiymiş. Toplam kaç yolcu sorduğu için $28^{\prime} l e 15^{\prime} i$ toplamış 43.

Farklı bir şekilde Çözüm- 2 üzerine yapılan görüşmede bazı öğrenciler ( $f=4)$ çözümde verilen eksik çözümü belirtmekle kalmamış, çözüm yapılması gerekenleri de belirtmiştir. Örneğin Ö20, Ö16 ve Ö17 kodlu öğrenciler, gördüğü problem cümlesine dayalı olarak verilen çözümü anlatması istendiğinde, çözümü açıklamakla kalmamış sorulmamasına rağmen problemdeki eksiği fark ederek hatanın giderilmesi için yapılması gerekeni de belirtmiştir.

Ö20: Bir tane araç çizmiş A aracı 5 kişilik olduğu için içine 5 yolcu çizmiş. B aracı da 7 kişilikmiş. 1 tane araba çizmiş yine içine 7 tane yolcu çizmiş. Sonra 7'yle 5'i toplamış 12 yolcu demiş. Burada bir aracın yolcu saylsı bulunmuş. Ama 3 tane A model aracın ve 4 tane B modelin bulmallydl.

Ö16: 5 kişilik dediği için 5 tane kişi yapmış. B modelinde de 7 kişiliktir deyince 7 tane kişi yapmış. Doğru gitmiş ama devam etmesi gerekiyordu. Önce 5'le 3'ü çarpacaktı 3 tane A aracı olduğu için sonra B'de de 4'ü 7'yle çarpıp sonra toplayacaktt.

Ö17: Bu da bir araç yapmış içine 5 tane kişi yapmış sonra B aracına 7 kişi yapmış bunları toplamış 12 yapmış. Bu bir tane aracı toplamış 3 ve 4 araç diyordu onları toplamamış. Araç sayısı farklı.

\section{Problemden Bağımsız Yalnızca Verilen Çözüme Odaklanma}

Çalışmaya katılan 23 öğrenciden 4'ü her ne kadar kendilerine problem cümlesi gösterilmiş olsa da bu durumu dikkate almayıp yalnızca öğrenci çözümüne odaklanmışlardır. Bu durum öğrencilerin hem problemi dikkatle okumadığı hem de okumuş olsa bile dikkate almayıp yalnızca çözümü betimleme yoluna gittiklerini düşündürmüştür. Örneğin:

Ö15: Arabanın içindeki kişileri toplamış.

Ö7: Arabanin içine 5 çocuk çizmiş.

Ö1: Bu araca 5 kişi koymuş, diğerine de 7 kişi koymuş. 7’yle 5 'i toplamış 12 bulmuş. Doğru bulmuş.

Öğrenciler ifadelerinde daha çok 'çarpmış, toplamış, bulmuş' gibi ifadeler kullanmışlar, ancak neden böyle yapıldığı konusunda fikir yürütememişlerdir. Başka bir deyişle öğrenciler yalnızca verilen resimdeki sayılara ve bu sayılarla yapılan işlemleri sözel bir şekilde ifade etmişlerdir. Ayrıca bulunan sonucu da doğru kabul etmişlerdir.

\section{Problemi ve Verilen Çözümü Anlayamama}

Çözüm-1 üzerine yapılan konuşmalarda 23 öğrenciden 6'sının problemi ya da çözümü anlayamadıkları görülmüsştür. $\mathrm{Bu}$ gruptaki öğrencilerin verilen modeli anlamadıkları, problemde verilenlerle ilişkilendiremedikleri göze çarpmaktadır. Ayrıca kullanılan matematik dilinde de kavramları hatalı kullandıkları da görülmektedir. Örneğin, Ö12 kodlu öğrencinin verilen örnekte hangi temsilin neyi ifade ettiğini kavrayamamış olmasından doğan bir ifadelendirme problemi göze çarpmaktadır. Bu örnek öğrencinin kavrayışındaki bir güçlüğün ortaya çıkarılması bakımından önemli görülmektedir. Başka bir açıdan ise bu tür görüşmeler çocukların hatalarının da ortaya çıkmasında yardımcı olmaktadır. Örneğin, öğrenci "kare" biçimindeki şekillere "küp" demektedir. 
Ö12: Burada olan küp sayısıyla 3'ü çarpınca 15 çıtkııs. 3'le 5'i çarpınca 15 çıkmış. Burada da 7 küp var 4 'le çarpınca 28 çıkmış. Sonra bunları toplamış. Sonuç da 43 çıkmış.

A. 15 neyi ifade ediyor?

Ö12: A modelini.

A: 28 neyi ifade ediyor?

Ö12: Küp sayısıyla 4'ün çarpımını.

A: Kare saylsı neyi ifade ediyor?

Ö12: (cevap yok)

Bunun gibi örneklerde öğrencilerin matematik dilini kullanarak açıklama yapamadığı görülmektedir. Zayıf anlatım gerçekleştiren öğrencilerin yaşadığı zorluk, çözümlerdeki gösterimlerin problemin hangi özelliğiyle ilişkili olduğunun kavranamaması/açıklanamaması olarak kendini göstermektedir. Örnekler incelendiğinde zayıf matematiksel anlatım ile güçlü anlatımın birbirinden ayrıldığı noktalar kolaylıkla fark edilmektedir. Öğrenciler bir başkasının çözümünü değerlendirirken çözümü gerçekleştiren kişinin kullandığı temsillerle (kutular, insan temsilleri vb.) problem bağlamı arasında ilişki kurarak problemi yorumlayabilmelidir. Örneğin çözümlerde niçin belirli sayıda kutu çizildiği, bu çizimlerin neyi ifade ettiğinin anlaşılması ve '... olduğu için ... yapmış' ifadelerinin kullanılması öğrencilerin güçlü bir matematiksel anlatıma sahip olduğunu gösterir. Burada kullanılan örnek problemde A model araçların 5 kişilik olduğu ve bu araçlardan 3 tane yola çıkacağı için çarpma işlemi yapılarak 15'e ulaşıldığı açıklanabiliyor olmalıdır.

\section{Bir Başkasının Stratejisini Anlama}

Bir başkasının stratejisini anlama becerisinin değerlendirilmesi aşamasında öğrencilerden çözümlerde kullanılan stratejileri belirlemeleri istenmiştir. Bu amaçla her iki çözümün sayısal sonucu aynı iken çözümün görsel temsili farklılaşmakta olan Çözüm-1 ve Çözüm-3 kullanılmıştır. Öğrencilerden çözüm stratejilerdeki bu farkın nedenini açıklamaları istenmiştir. Çalışmaya katılan 23 öğrenciden 14'ü kolaylıkla farklı stratejilerin nedenini açıklamıştır. Bu soruya verilen yanıtların bir başkasının stratejisini değerlendirmede önemli bir gösterge olduğu düşünülmektedir.

Ö16: Burada (Çözüm-1) araç 5 kişiliktir demiş 5 kişiliği ve bir aracın kaç kişilik olduğunu göstermiş. Burada (Çözüm-3) A modeli 5 kişilik ama toplam 3 aract var onları çarpıp A modelinde kaç kişi bindiğini göstermiş, 3 tane araçta kaç kişi olduğunu.

Ö17: Bu (Çözüm-1) bir araçtaki kişileri çizmiş kutu yapmış. Bir araç var 3 tane olduğunu sayıyla belirtmiş. Burada (Çözüm-3) ise toplamı yapmış. Tüm araçları çarpıp kutuyla belirtmiş.

Ö18: Burada (Çözüm-1) 1 aracın 5 kişilik araç olduğu göstermiş. Bu (Çözüm-3) sadece toplamı yapmış toplam gidenleri kutu yapmış.

Ö19: Aynı şey değil çünkü bu (Çözüm-1) önce 5 tane kutu yapmış 3 ’le çarpmış. Bu da (Çözüm-3) önce çarpmuş sonra kutu yapmış.

Ö20: Burada (Çözüm-1) tek bir A arabanın kaç yolcu aldı̆̆ını göstermiş. Burada (Çözüm-3) A modelden 3 tane çıkmış yani 3 tane A model araba yola çıkınca kaç yolcu olduğunu göstermiş.

Örnek olarak kullanılan problemde 1 adet $A$ ve 1 adet $B$ araçlarının aldığı kişi sayısını kutuyla gösterilerek çarpmanın yapıldığı ve toplamda 3 adet $A$ aracının ve 5 adet $B$ aracının aldığı kişi sayısının kutularla gösterildiği ve sonunda toplama işlemi yapıldığı iki farklı çözüm öğrencilere sunulmuştur. Örnek cevaplarda görüldüğü üzere öğrenciler çözüm stratejileri arasındaki farkı kolaylıkla açıklamıştır ve gösterimlerdeki farklı kutu sayısının işlemlerin yapılışı ile bağlantısını fark ettiklerini bildiren söylemlerde bulunmuşlardır. Bu durum öğrencilerin farklı stratejileri anlama ve değerlendirmeyi rahatlıkla gerçekleştirebildiğini göstermektedir. 


\section{Bir Başkasının Stratejisini Değerlendirme}

Takip eden bir etkinlik olarak bir başkasının stratejisini değerlendirme becerisinin belirlenmesi kapsamında öğrencilerden Çözüm-1 ve Çözüm-2'yi karşılaştırmaları istenmiştir. Bu aşama için tercih edilen çözümlerin görsel temsil türü ve işlemler bakımından farklı olması dikkate alınmış ve öğrencilerin bu farkları ayırt edip edemeyecekleri yoklanmıştır.

\section{Verilen Çözüme Dayalı Açıklama}

Elde edilen bulgulara göre öğrencilerin $15^{\prime} i$ akranlarının hem işlemsel hem de görsel gösterimlerini değerlendirmede sorun yaşamamıştır.

Ö3: Gösterdiği kişi sayısı farklı burada kutuları insan yerine saysak aynı. Burada (Çözüm-1) kutu var. Burada (Çözüm-2) araç ve insan çizmiş. Bir de eksiklik var burada.

Ö13: Burada (Çözüm-1) kutu olarak göstermiş. Gösteriş farkl. Burada (Çözüm-2) 5 'i insan olarak göstermiş.

Ö14: İkisi de toplama var bu (Çözüm-1) kısa yoldan toplama yapmış. Araba ve kişilerle benziyor. Kişi saylsl farkl.

Ö8: Sayı ve işlem yapmış kareler var. Birinde (Çözüm-2) şekil çizerek yapmaya çalışmış.

Ö9: İkisi de model olarak göstermiş. Bu (Çözüm-1) çarpmış ve araçla çarpmış. Farkl yöntem kullanmış çünkü bu ögrenci blokla göstermiş karelerle göstermiş. Bu (Çözüm-2) direkt kişileri toplamış ama bu resim çizmiş.

\section{Problemden Bağımsız Yalnızca Verilen Çözüme Odaklanma}

Çalışmaya katılan 3 öğrenci akranlarının stratejilerini karşılaştırırken sorun yaşamıştır. Bu aşamada kullanılan Çözüm-1 ve Çözüm-2'yi görsel temsil türü ve işlemler bakımından değerlendirmeyip yalnızca öğrenci çözümü betimleme yoluna gitmiştir. Örneğin:

Ö21: Bu direkt 15 kişi bunları toplamış B' de de 28 kişi bunları yapmış toplamış.

Ö11: Önce 5 kişilik var hemen 3'le çarpmış.

\section{Verilen Çözümü Değerlendirirken Eksiklikleri Belirleme ve Öneri Sunma}

Çalışmaya katılan 23 öğrenciden 5'i örneklerde görüldüğü gibi iki çözüm arasındaki görsel temsil temelli farkları kavrayıp kendi cümleleriyle ifade etmiştir. Bu etkinlik öğrenciler için hem karşılaştırma hem de kavrama becerileri açısından oldukça önemlidir. Öğrenciler bu yorumları yaparken aslında Çözüm- 2'deki stratejinin eksik yönlerini vurgulayan cümleler kurmuştur.

Ö14: Burada çarpma eksik. Çünkü 3 tane A var 4 tane B var.

Ö5: 7'yle 5'i toplamış. Toplama doğru ama burada diyor ki 3 tane A aracı ve 4 tane araç yola çıkmış. Araçları eksik çizmiş.

Ö2: A aracının kişi sayısını göstermiş. B'yi de göstermiş. Zaten A 5 kişilik diyor ama 3 tane var diyor. Bu yanlış yapmış direkt kişi sayısını bulmuş. B araçta da böyle yapmış. Araba sayısı eksik.

Ö4: Eksik olan bunları toplamış. 7'yle 4'ü çarpmalıydı. 5'le de 3'ü çarpmalıydl.

Bir başkasının stratejisini değerlendirirken öğrencilerin problemdeki verilenleri ve istenenleri anlama, kurallar üzerinden başkasının çözüm yöntemini açıklama, temel kavramlara atıf yaparak ve farklı stratejiler üzerinden başkasının çözüm yöntemini açıklama, bir başkasının hata ve eksikliklerini belirleme aşamalarından geçtiği görülmektedir.

\section{Uygulamanın Kazandırdıkları}

Araştırma kapsamında öğrencilerle yapılan konuşmalar sonlanırken yapılan bu etkinliğin onlar için nasıl bir deneyim olduğuyla ilgili sorular da sorulmuştur. Bu kategori altında veriler incelendiğinde öğrenciler bu uygulamanın daha çok strateji kazanmalarına katkısı olduğunu, yanlış çözümlerden ders aldıklarını, 
çözümün kontrol edilmesi gerekliliğini ve verilen durumun problemin anlaşılmasını kolaylaştırdığını belirtmişlerdir. Örneğin:

\section{Ö3: Bir soruyu ikiden fazla farklı şekilde yapabileceğimizi gösterdi.}

Ö5: Bunların sorusu aynı ama işlemleri farklı sonuçları da farklı olabileceğini gördüm.

\section{Ö7: Mesela yanlı̧̧ çözümlerimizde bunlar aklımıza gelir.}

Ö8: Doğrudan yanlışı ayırıyoruz. Yanlışı bulunca bir dahakine doğruyu yaparız yanlışı yapmayız.

Ö9: Mesela herkes doğru sonucu bulamayabilir farklı sonuçlar verebilir farklı sonuçlar bulabilir. Mesela hangisinin doğru olduğunu ögreniriz. Dikkatli olmamızı problemi yapınca kontrol etmemizi. Soruyu okuduk anlamadığımızı düşünürsek bir daha okumamızı.

\section{Ö13: Beynimizi geliştirir. Problemin sonucunu görürüz.}

\section{Ö14: Böyle görmek soruları daha kolay yapıyor.}

Öğrencilerin yapılan karşılaştırma etkinliğine yönelik olarak olumlu ifadeler kullandığı ve farklı çözümleri görmeyi bir öğrenme aracı olarak görüldüğü söylenebilir. Bu etkinliklerin sınıf içinde küçük gruplarla ya da birebir konuşmalarla gerçekleştirilmesinin hem öğrenci hem de öğretmenler için eğlenceli ve verimli, üretken bir öğrenme ortamı yaratacağı düşünülmektedir.

\section{TARTIŞMA VE SONUÇ}

Matematiksel dilin kullanımı üzerine elde edilen bulgulardan yola çıkarak, ilkokul dördüncü sınıf öğrencilerinin kendi fikirlerini matematik dilini kullanarak ifade etme durumlarına yönelik ulaşılan sonuçlara göre, öğrencilerin matematiksel bir durum hakkında konuşurken problem bağlamını ve çözümü kavrayıp metin ve çözüm arasında ilişki kurabildikleri, bu ilişkiyi cümlelerinde neden-sonuç ifadelerine yer vererek açılayabildikleri görülmektedir. Öğrencilerin bazıları ise sunulan matematiksel durumu (çözümü) betimlemenin ötesine gidemedikleri görülmüştür. Bu sonuçlar öğrenme ortamlarında öğrencilerin kavrama düzeylerinin ortaya çıkarılmasında onlara konuşma imkânı sunmanın önemli bir öğrenme ve düzey belirleme aracı olduğunu düşündürmektedir.

Çalışmadan edinilen bulgulara göre, öğrencilerin matematiksel bir durum hakkında konuşurken kullandıkları dilin güçlü veya zayıf olması, aynı zamanda öğrencinin problem bağlamını kavrama düzeyiyle ilgili olduğu söylenebilir. Öğrenci sunulan bir matematik çözümünü değerlendirmek için önce problemi okur ve çözüm ile problemin metni arasında bir ilişki kurar. Problem metninin anlaşılması ve ilişkilendirme becerisi bireyde geliştikçe bu gelişim matematiksel ifadelerde kendini gösterir. Bu fikri destekleyen Schleppegrell'e (2007) göre dil, durum hakkında bağlamsal bilgi sağlar, matematik sembolizmi varlıklar arasındaki ilişkilerin desenini tanımlar ve gerçek hayat ile problemde inşa edilen matematiksel süreçler arasında bir bağlantı kurar. Benzer şekilde Chi'e (2000) göre bir açıklama oluşturma sürecinde öğrenciler durumun belirgin özellikleri hakkında düşünebilir ve problemleri çözmek için belirli çıkarım kuralları oluşturma ve hatalı zihinsel modellerini onarma konusunda kendi içlerinde açıklama yapabilirler. Bu durum öğrencilerin kendi bilgilerini kontrol etmesi yani üstbiliş becerileri ile yakından ilişkilidir.

Öğrencilerin teknik kelimeleri, matematikte anlamlı hale gelecek dil kalıplarında kullanabilmeleri gerekir. Sadece matematiksel kelimeleri bilmek yeterli değildir; öğrencilerin ayrıca bu kelimelerle bağlam içinde açıklayarak kullanmalıdır. Moschkovich' in (1999) belirttiği gibi, öğrenciler konuşmalara hem sözlü hem de yazılı olarak çözüm süreçlerini ve varsayımları açıklayarak, sonuçları kanıtlayarak ve argümanlar sunarak katılmalıdır. Öğrencilerin genişletilmiş biçimlerinin gelişimini teşvik etmenin bir yolu olan matematik hakkında konuşmak, öğrencilerin birbirleriyle konuşmalarını sağlamaktır. Öğrencileri matematik kavramlarını tartışmak üzere gruplandırmak, sınıfta öğretmen merkezli bir ortamın oluşmasını sınırlandıracağından, matematik dersliklerinde grup çalışması ve tartışma ortamları yaygınlaştırılmalıdır.

Tartışma ve konuşma ortamları öğretmenler için de oldukça önemlidir. Öğrencilerin fikirlerini açıkladıkları ve yöntemlerini tartıştıkları durumlar, öğretmenlere kendi matematik anlayışlarını yeniden düşünme ve derslerini öğrencilerin ihtiyaçlarına göre planlama firsatı verir (Beaton, 1994; Cobb, Yackel 
ve Wood, 1992). Öğrencilerin öğrenmelerini geliştirme ve öğretmenlerin uygulamalarında da değişikliklere zemin hazırlaması bakımından bir başkasının matematiğini tartışma oldukça verimli bir etkinlik olarak görülmektedir. Araştırma sonuçlarını destekler şekilde O'Halloran (2000) matematik sembolizmindeki anlamları açmak ve öğrencilerin matematik için anlam ifade etme biçimlerini çizmelerine yardımcı olmak için matematiğin çok yönlü yapısını kullanmanın bir yolu olarak sözlü dilin tartışma ortamları içinde kullanması gerektiğini belirmiştir. Bu yöntem ile öğrencilerin kavrama süreçlerindeki hataların görünür kılındığı söylenebilir.

Başkasının stratejisinin değerlendirilmesi konusunda ise tüm dil gelişiminde olduğu gibi, öğrencilerin anlamlı bir söylem inşa ettikleri etkileşimli etkinliklerde matematiği kullanma firsatlarına ihtiyacı vardır. Hem bu firsatın verilmesi hem de öğrencilerin matematiksel bir içerik olarak bir problemi değerlendirilme sürecindeki içsel durumunu görmemizde bir araç olarak örnek çözümler üzerinden strateji değerlendirmesi yapmak oldukça kullanışlıdır. Çalışma kapsamında elde edilen bulgulara göre öğrencilerin bir başkasının stratejisini değerlendirirken problemdeki verilenleri ve istenenleri anlama, kurallar üzerinden başkasının çözüm yöntemini açıklama, temel kavramlara atıf yaparak ve farklı stratejiler üzerinden başkasının çözüm yöntemini açıklama, bir başkasının hata ve eksikliklerini belirleme aşamalarından geçtiği görülmüştür. Tüm bu adımlar öğrencilerin kavram bilgisi, işlem bilgisi, analiz etme becerisi, eleştirel düşünme becerisi gibi kritik bilgi ve becerileri ile ilişkilidir. Sınıf içi uygulamalarda bu tür karşılaştırma, çözümünü anlatma, başkasının çözümü üzerinden kendi fikirlerini matematiksel olarak ifade etme temelli etkinlikler yapılması öğrenciler için eğlenceli ve geliştirici olacaktır. Yapılan araştırmalar bulguları destekler niteliktedir. Örneğin öğrencilerden kullandıkları stratejileri detaylıca anlatmaları istendiğinde öğrencilerin daha yüksek bir matematik performansı sergilediğini görülmüştür (Webb ve diğerleri, 2014). Öyleyse bir başkasının stratejisini değerlendirmek hem eleştirel düşünmeyi hem de kendisinden önceki anlama basamağını içerdiğinden öğrenciler için geliştirici olduğunu söylemek mümkündür.

Öğrenciler başkalarıyla konuşmaları sırasında düşüncelerini detaylandırdıkları zaman bilişsel bir ayrıntılandırma perspektifine göre (O'Donnell, 2006) kendi bilgi ve anlayışlarını yeniden yapılandırmaya katılmaya yönlendirilmiş olurlar. Çalışmada yapılan etkinlikte de öğrenciler bir durumu değerlendirmeyi kendi ifadeleriyle 'doğruyu yanlışı ayırmalarını sağlayan, bir sorunun farklı şekillerde çözülebileceği gösteren' bir deneyim olarak belirtmişlerdir. Destekler nitelikte, Bargh ve Schul'a göre (1980) yeni stratejiler ve bilgiler edinerek yeni bakış açıları ve anlayış geliştirmek; materyali başkalarına açıklamaya, açıklanacak bilgiyi prova etmeye, materyali yeniden düzenlemeye ve açıklığa kavușturmaya, kendi kavram yanılgılarını tanımaya, kendi anlayışlarındaki boşlukları doldurmaya, yeni bilgiler ve önceden öğrenilen bilgiler arasındaki bağlantıları güçlendirmeye, içselleştirmeye teşvik ederek öğrenmeyi güçlendirir.

Öğrencilerin açıklamalarını dinlemek, öğretmenin ve diğer öğrencilerin bir öğrencinin düşüncesi hakkında daha fazla bilgi edinmesine yardımcı olmakla kalmaz, aynı zamanda öğrencinin paylaşmayı iki önemli şekilde yapmasına yardımcı olur. Öncelikle, paylaşım öğrencinin anlayışını geliştirmesine yardımcı olur çünkü sözlü olarak matematiksel fikirler arasında bağlantılar kurabilir ve derinleştirebilir. İkinci olarak, paylaşım öğrencinin matematiksel bir açıklamada neyin önemli olduğunu öğrenmesini sağlar. Bilişsel yaklaşım açısından baktı̆̆ımızda öğrencilerin birbirinin stratejilerini değerlendirmesi, stratejiler üzerinden eleştirme ve tartışma ortamlarını yaratması yüksek akı1 yürütme ve öğrenme düzeylerine temel oluşturmaktadır; çünkü öğrenme, şemalarda yaşanan dengesizlik durumları sonucunda ortaya çıkar. Benzer șekilde sosyal yapılandırmacılıkta belirtildiği gibi birlikte öğrenme ortamları öğrencilerin birbiri ile müzakere ederek öğrendiği bir süreç gerçekleştirmesine olanak tanır. Yapılan çalışmalar da ayrıntılı tartışma ortamları ve öğrenme çıktıları arasındaki güçlü ilişkiyi ortaya koymaktadır (Webb ve diğerleri, 2014; Webb ve diğerleri, 2017; Webb, 2009; Webb, Franke, De, Chan, Freund, Shein, ve Melkonian, 2009). Öyleyse öğrencilerin problemleri analiz etme, problem durumları üzerine konuşarak kendi matematiksel fikirlerin matematik dilini kullanarak ifade etme ve başkasının stratejisini anlama ve değerlendirmeye yönlendirilmesi matematiğin temel bileşenlerinden olmalıdır.

\section{SINIRLILIKLAR VE GELECEK ARAŞTIRMALAR}

$\mathrm{Bu}$ çalışma birtakım sınırlılıklara sahiptir. İlk sınırlılığı çalışma grubuna dâhil olan öğrencilerin sayısı oluşturmaktadır. Çalışma grubuna dahil edilen 23 öğrenciden elde edilen verilerin gerçeği temsil edişi 
sınırlıdır. Araştırmanın ikinci sınırılığı ise öğrencilerin bir başkasının stratejisini anlama ve buna yönelik fikirlerini, matematik dilini kullanarak ifade etme durumlarının görüşme aracılıyla incelenmiş olmasıdır. Öğrenciler sınıflarında veya herhangi bir tartışma ortamında gözlenmemiştir. Araştırmanın üçüncü sınırlılığı verilerin öğrencilere sunulan üç örnek çözüm kağıdı aracıllı̆̆ıla elde edilmesidir. Her ne kadar veri toplamada kullanılan çözüm örnekleri öğretim programına uygun ve uzman görüşü eşliğinde belirlenmiş olsa da araştırma kapsamında elde edilen veriler bu çözümler üzerine yapılan konuşmalara yönelik olması yönüyle sınırlıdır. Bu araştırmanın sunduğu verilerin öğrenci konuşmalarının hangi durumlarda süreci destekler nitelikte olacağına yönelik öngörüde bulunma imkanı sunduğu düşünülmektedir. Ancak bu çalışma öğrencilerin bir başkasının stratejisini değerlendirme durumu veya matematik dilini kullanma durumlarının hangi etmenlerce şekillendirildiğini açıklamamaktadır. $\mathrm{Bu}$ sınırlılığın giderilmesi ve araştırma bulgularının desteklenmesi için öğrencilerin tartışma gruplarında yapılacak gözlemlerle zenginleştirilmiş araştırmaların yapılması önerilebilir. Ayrıca bu çalışmanın; sınıf düzeyi, problem çözme alanı dışında bir konu, farklı akademik başarı düzeylerine sahip öğrenciler vb. değişkenler gibi çeşitlemelerle gerçekleştirilmesi ve bulguların karşılaştırılması tavsiye edilebilir. Son olarak öğrencilerin bir başkasının stratejisini anlama ve buna yönelik fikirlerini, matematik dilini kullanarak ifade etme durumlarının farklılaşmasında etkili olan faktörlerin belirlenmesine yönelik keşfedici araştırmaların yapılması önemli bir eksikliği dolduracaktır.

\section{UYGULAMAYA DÖNÜK DOĞURGULAR}

Araştırma bulguları üzerinden yapılan çıkarımların öğrencilerin bir başkasının stratejisini anlama ve buna yönelik fikirlerini, matematik dilini kullanarak ifade etme durumlarının anlaşılmasına katkı sağlayacağı düşünülmektedir. Araştırma bulgularının 'Öğrencilerin bir başkasının stratejisini anlama durumları üzerine yapılan bu betimleme ne tür bir strateji öğretimi programına kaynaklık edebilir? $\mathrm{Bu}$ öğretim programları öğrencilerin strateji değerlendirme ve matematik dilini kullanma performansının yükseltilmesinde destekleyici olabilmek için hangi değişkenlerin etkisinde kalmaktadır? Bu değişkenler nasıl kontrol altına alınabilir veya kullanılabilir?' Sorularına ilişkin çıkarımlarda bulunmayı olanaklı kılan bir zemin olarak ele alınması önem taşımaktadır. Bu sorular ve sunulacak cevaplar, öğrenci performansını bir üst basamağa çıkarmayı amaçlayan öğretmenler ve eğitim araştırmacıları için önem taşımaktadır. Araştırma sonuçlarında bildirildiği üzere öğrencilerin bir bölümü stratejileri değerlendirmesi beklenirken doğrudan betimleme yoluna gitmiştir. Bu durumun çeşitli yönlendirmelerle giderilmesi öğretmenlerin sınıflarında yapabileceği bir uygulamadır.

Bilgilendirme / Acknowledgement: Bu çalışma Uluslararası Sınıf Öğretmenliği Eğitimi Sempozyumu'nda (USOS2019) sözlü bildiri olarak sunulmuştur.

\section{KAYNAKÇA}

Alkan, H. ve Güzel, E. B. (2005). Öğretmen adaylarında matematiksel düşünmenin gelişimi. Gazi Üniversitesi Gazi Ĕ̈itim Fakültesi Dergisi, 25(3), 221-236.

Bali, G. Ç. (2002). Matematik öğretiminde dil ölçeği. Hacettepe Üniversitesi Eğitim Fakültesi Dergisi, 23(23), 57-61.

Bargh, J. A.ve Schul, Y. (1980). On the cognitive benefits of teaching. Journal of Educational Psychology, 72(5), 593.

Beaton, A. E. (1996). Mathematics Achievement in The Middle School Years. Boston: TIMSS International Study Center.

Bilgin, N. (2014). Sosyal bilimlerde içerik analizi: teknikler ve örnekler çalışmalar. İstanbul: Siyasal Kitabevi.

Bogdan, R. C. ve Sari Knopp Biklen, S. K. (2007). Qualitative research for education: An introduction to theories and methods, (5th Edition). Boston, MA: Pearson. 
Chi, M. T. H. (2000). Self-explaining expository texts: The dual processes of generating inferences and repairing mental models. In R. Glaser (Ed.), Advances in instructional psychology: Educational design and cognitive science (pp. 161-238). Hillsdale, NJ: Erlbaum.

Cobb, Yackel ve Wood. (1992). A Contructivist altenrnative to the representational view of mind in mathematics education. Journal for Research in Mathematics Education, 23, 2-33.

Common Core State Standards Initiative (CCSSI). (2010). Common core state standards for mathematics. Washington, DC: National Governors Association Center for Best Practices and the Council of Chief State School Officers.

Creswell, J. W. ve Miller, D. L. (2000). Determining validity in qualitative inquiry. Theory into practice, 39(3), 124-130.

Çalıkoğlu-Bali, G. (2003). Matematik öğretmen adaylarının matematik öğretiminde dile ilişkin görüşleri. Hacettepe Üniversitesi Ĕ̈itim Fakültesi Dergisi, 25, 19-25.

de Garcia, L. A. (2013). How to get students talking! Generating math talk that supports math learning. $1 \quad$ Mayis 2019 tarihinde https://mathsolutions.com/documents/how_to_get_students_talking.pdf adresinden erişildi.

Dreyfus, T. (2007). Processes of abstraction in context the nested epistemic actions model. Journal for Research in Mathematics Education, 32, 195-222.

Ekiz, D. (2003). Ĕgitimde araştırma yöntem ve metotlarına giriş: nitel, nicel ve eleştirel kuram metodolojileri. Ankara: Anı Yayınc1l1k.

Halliday, M. A. K. (1978). Language as social semiotic. London: Edward Arnold.

Hintz, A. (2014). Strengthening discussions. Teaching Children Mathematics, 20(5), 318-324.

Hintz, A. ve Kazemi, E. (2014). Talking about Math. Educational Leadership, 72(3), 36-40.

Karasar, N. (2016). Bilimsel araştırma ve yöntemi (30. baskı). Ankara: Nobel Yayın Dağıtım.

Mayer, R. E. (1985). Implications of cognitive psychology for instruction in 94 mathematical problem solving. Teaching and learning mathematical problem solving: Multiple research perspectives, 123-138.

Maykut, P. ve Morehouse, R. (1994). Beginning qualitative research: A philosophical and practical guide. London: Falmer.

Milli Eğitim Bakanlığı. (2018). Matematik dersi öğretim programı (İlkokul ve Ortaokul 1, 2, 3, 4, 5, 6, 7 ve 8. Sinıflar). Ankara: Milli Eğitim Basımevi. 1 Mayıs 2020 tarihinde http://mufredat.meb.gov.tr/ProgramDetay.aspx?PID=222 sayfasından erişilmiştir.

Moschkovich, J. N. (1999). Supporting the participation of English language learners in mathematical discussions. For the Learning of Mathematics, 19(1), 11-19.

National Council of Teachers of Mathematics. (2000). Principles and standards for school mathematics.

O'Donnell, A. M. (2006). The role of peers and group learning. P. Alexander \& P. Winne (Eds.) Handbook of educational psychology içinde. (2nd ed.). Mahwah, NJ: Lawrence Erlbaum.

O'Halloran, K. L. (2000). Classroom discourse in mathematics: A multisemiotic analysis. Linguistics and Education, 10(3), 359-388.

Organisation for Economic Co-operation and Development (OECD). (2018). The future of education and skills: Education 2030.

Polya, G. (2006). How to Solve It. Princeton and Oxford: Princeton University.

Schleppegrell, M. J. (2007). The linguistic challenges of mathematics teaching and learning: A research review. Reading \& Writing Quarterly, 23(2), 139-159. 
Senemoğlu, N. (2018). Gelişim öğrenme ve ögretim: Kuramdan uygulamaya. Ankara: Anı Yayınc1lı. Silverman, D. (2005). Doing research: A practical handbook (2nd ed.). London: Sage

Umay, A. (2002). Öteki matematik. Hacettepe Üniversitesi Eğitim Fakültesi Dergisi, 23(23), 275-281.

Webb, N. M. (2009). The teacher's role in promoting collaborative dialogue in the classroom. British Journal of Educational Psychology, 79(1), 1-28.

Webb, N. M., Franke, M. L., De, T., Chan, A. G., Freund, D., Shein, P. ve Melkonian, D. K. (2009). 'Explain to your partner': teachers' instructional practices and students' dialogue in small groups. Cambridge Journal of Education, 39(1), 49-70.

Webb, N. M., Franke, M. L., Ing, M., Turrou, A. C., Johnson, N. C. ve Zimmerman, J. (2017). Teacher practices that promote productive dialogue and learning in mathematics classrooms. International Journal of Educational Research, 1-11.

Webb, N. M., Franke, M. L., Ing, M., Wong, J., Fernandez, C. H., Shin, N. ve Turrou, A. C. (2014). Engaging with others' mathematical ideas: Interrelationships among student participation, teachers' instructional practices, and learning. International Journal of Educational Research, 63, 79-93.

Yetkin Özdemir, İ. E. ve Pape, S. J. (2013). The Role of interactions between student and classroom context in developing adaptive self-efficacy in one sixth-grade mathematics classroom. School Science and Mathematics, 113(5), 248-258.

Yıldırım, A. ve Şimşek, H. (2011). Sosyal Bilimlerde Nitel Araştırma Yöntemleri (8. Baskı). Ankara: Seçkin Yayıncılık.

Yin, R. K. (2003). Case study research, designs and methods (3rd Edition). California: Sage Publications. 